\title{
PRAVILA I STANDARDI ZA BEZBEDNOST PUTNIČKIH BRODOVA
}

\begin{abstract}
Iris BJELICA VLAJIĆ*
Apstrakt: Korišćenje pomorskih plovnih puteva za transport ljudi i robe je u stalnom porastu. Uprkos razvoju tehnike, korišćenju novih materijala i povećanju gabarita brodova, gubitak ljudskih života na moru je i dalje veliki. Razlog za to leži u nepoštovanju osnovnih pravila vezanih za kapacitet broda ili njegove tehničke mogućnosti. Globalne i regionalne organizacije ulažu napor da donesu i usaglase različite standarde kojim bi se povećala bezbednost putnika i članova posade. Pravila se kreću od poboljšanja uslova za život i rad na brodu, izjednačavanja i priznavanja svedočanstava o obrazovanju i osposobljenosti posade, usvajanja detaljnih tehničkih pravila vezanih za izgradnju, prepravke i opremanje brodova, ali i kategorizacije brodova kako bi im se ograničilo kretanje na morske pojaseve prema konstrukcijskim mogućnostima koje imaju. Pojedine članice Evropske unije zahvaljujući geografskim specifičnostima imaju posebne potrebe u pogledu korišćenja pomorskih puteva. Organi Evropske unije usvojili su određeni broj zakonodavnih akata, od kojih je najnoviji Direktiva 2017/2108/EU. Cilj je usaglašavanje EU zakonodavstva sa postojećim međunarodnim standardima, ali i usaglašavanje zakonodavstava država članica međusobno, kao i uklanjanje neželjenih negativnih posledica koje su raniji akti proizveli.

Ključne reči: EU zakonodavstvo, putnički brod, međunarodni standardi.
\end{abstract}

\section{1) UVOD}

Pomorske nesreće putničkih brodova Titanik, MS Estonija, Kosta Konkordija, kao i nekoliko nesreća trajekta u Aziji koji su za posledicu, osim materijalne štete, imali i veliki broj izgubljenih ljudskih života, uticale su na pooštravanje propisa koji se odnose na bezbednost putničkih brodova. Agencija UN koja se bavi pitanjima bezbedne plovidbe, Međunarodna pomorska organizacija (IMO), usvojila je nekoliko konvencija, od kojih se Međunarodna konvencija o zaštiti ljudskog života

\footnotetext{
${ }^{*}$ Prof. dr Iris Bjelica Vlajić je predavač pravne grupe predmeta u Visokoj brodarskoj školi akademskih studija, Beograd, e-mail: iris_bjelica_vlajic@yahoo.com
} 
na moru, sa naknadnim izmenama i dopunama (SOLAS) i Konvencija o teretnim linijama 1966, smatraju najznačajnijim.

Definicija po kojoj je putnički brod sa sopstvenim pogonom registrovan za prevoz više od 12 putnika, prilično je široka. Da bi se obuhvatile različite vrste plovila namenjene prevozu ljudi bilo je potrebno doneti detaljna pravila kojima se propisuju standardi za bezbednu plovidbu. Pored toga, zahteve koji proizlaze iz Konvencije SOLAS 1974. teško je prilagoditi malim putničkim plovilima dužine manje od 24 metra. Skupština IMO usvojila je, krajem 2006. godine, dopune SOLAS konvencije koje se odnose na putničke brodove, smatrajući da postojeća pravila ne pružaju dovoljan nivo sigurnosti. Ova pravila posebno se odnose na brodove koji su u izgradnji, odnosno od postavljanja kobilice do momenta upisa u upisnik brodova.

Prve Direktive kojima je Unija nastojala propisati zajedničke mere za poboljšanje stepena sigurnosti brodova kojim se prevoze putnici bila je Direktiva 98/18/EZ. Jedanaest godina kasnije, ova Direktiva je zamenjena novom Direktivom 2009/45/EZ, koja je u primeni bila od 15. jula 2009. godine. Međutim, pokazalo se da su neka pravila vezana za putničke brodove bila nejasna ili komplikovana za implementaciju, što je dovelo do nejednake primene Direktive u svim članicama. U vreme donošenja Direktive 2009/45/EZ, njena primena je bila predviđena samo za putničke brodove i manji broj drugih plovila, za koje su osmišljene posebne sigurnosne norme. Iz područja primene izostavljene su neke vrste brodova, a posebno tenderi, jedrenjaci i brodovi kojima se, do odobalnih objekata, prevozi obučeno osoblje koje nije uključeno u poslovanje broda, kao i putnički brodovi koji nemaju mehanički pogon. ${ }^{1}$

Problem se javio i u pogledu korišćenja putničkih brodova izgrađenih od aluminijumske legure, koji se koriste za redovne pomorske veze među različitim lukama unutar države članice. Mali brodovi, takođe, uglavnom su izgrađeni od materijala koji nisu čelik. Vrlo ograničen broj takvih brodova odobren je u skladu s Direktivom 2009/45/EZ pa ih je bilo potrebno isključiti iz područja primene

\footnotetext{
${ }^{1}$ Tenderi koji se prevoze na brodu upotrebljavaju se za direktan prevoz putnika sa putničkih brodova do obale i natrag najkraćim sigurnim morskim plovnim putem. Nisu prikladni i ne bi ih trebalo upotrebljavati za druge vrste usluga, kao što su izleti radi razgledanja obale. Za te bi izlete trebalo upotrebljavati brodove koji ispunjavaju zahteve obalne države o putničkim brodovima, kao što je, među ostalim, navedeno u smernicama IMO-a (MSC.1/Circ. 1417 o smernicama za tendere putničkih brodova). Direktiva se ne odnosi na jedrenjake, ako je njihov mehanički pogon namenjen samo za pomoćnu upotrebu i upotrebu u slučaju nužde. Objekte udaljene od obale snabdevaju plovila koja prevoze industrijsko osoblje. To industrijsko osoblje mora uspešno završiti kurs obaveznog osposobljavanja u pogledu sigurnosti i ispunjavati obavezne kriterijume zdravstvene sposobnosti. Stoga bi se na njih trebala primenjivati različita i posebna sigurnosna pravila.
} 
direktive. Umesto pravila iz Direktive na njih se primenjuju posebne sigurnosne norme koje odrede države članice, jer one mogu bolje proceniti lokalna ograničenja plovidbe tih brodova u pogledu udaljenosti od obale ili luke i vremenskih uslova. Usklađivanje korišćenja takvih brodova sa zahtevima iz Direktive, stvorilo bi ozbiljne posledice po prevoznu delatnost zbog značajnih finansijskih i tehničkih posledica za postojeće i nove brodove.

Pomoć Komisiji u proceni provođenja Direktive 2009/45/EZ pruža Evropska agencija za pomorsku sigurnost (EMSA), putem poseta koje obavlja u lukama država članica. ${ }^{2}$ Države članice obavezne su da sarađuju sa Komisijom na prikupljanju svih informacija potrebnih za evaluaciju. Ni naknadne izmene i dopune nisu dovele do značajnijeg poboljšanja primene, pa je iz tog razloga 15. novembra 2017. godine usvojena Direktiva 2017/2108/EU. ${ }^{3}$ Nakon toga, usledile su Direktive kojima se regulišu pitanja registracije pomoraca na putničkim brodovima, bezbednosnim postupcima na ro-ro i brzim putničkim brodovima, i formalnostima koje brodovi imaju u vezi pristajanja i napuštanja luke država članica.

\section{2) ANALIZA DIREKTIVE}

Direktiva (EU) 2017/2108 od 15. decembra 2017. godine o izmeni Direktive 2009/45/EZ o sigurnosnim pravilima i normama za putničke brodove usvojena je na predlog Evropske komisije, uzimajući u obzir mišljenje Evropskoga privrednog i socijalnog odbora i Komiteta regiona, u skladu sa Ugovorom o funkcionisanju Evropske unije. ${ }^{4}$ Cilj Direktive je održavanje visokog nivoa sigurnosti u skladu sa zajedničkim bezbednosnim normama koje su utvrđene Direktivom 2009/45/EZ, uz istovremeno omogućavanje jednakih uslova za sve učesnike u vodnom saobraćaju. Pored toga, javila se potreba za ažuriranjem i usklađivanjem definicija iz Direktive sa povezanim međunarodnim pravilima ili pravilima Unije, a što bi doprinelo jasnoći i doslednosti. ${ }^{5}$

\footnotetext{
${ }^{2}$ Komisija bi trebala obaviti evaluaciju provođenje Direktive 2009/45/EZ do 21. decembra 2026. te o tome podneti izveštaje Evropskom parlamentu i Veću.

${ }^{3}$ Direktiva 2017/2108/EU, OJ L 315, 30.11.2017, pp. 40-51.

${ }^{4}$ Ugovor o funkcionisanju Evropske unije, OJ C 326/47, 2012, član 100, stav 2.

${ }^{5}$ Definicija tradicionalnog broda u pogledu godine izgradnje i vrste materijala, definicija jahte za razonodu i plovila za razonodu treba bolje uskladiti s Međunarodnom konvencijom o zaštiti ljudskog života na moru iz 1974. (Konvencija SOLAS 1974). Program za delotvornost propisa (REFIT) pokazao je da ne odobravaju sve države članice brodove od aluminijuma u skladu s Direktivom 2009/45/EZ, čime je stvorena nejednaka situacija i narušen zajednički nivo sigurnosti za putnike koji plove unutar Unije. Nejednaka primena Direktive proizlazila je iz različitih tumačenja definicije aluminijuma kao materijala i primenjivosti odgovarajućih normi za zaštitu od požara.
} 
Direktivom su date detaljnije definicije određenih pojmova. Država članica definiše područje luke nad kojim ima nadležnost, odnosno područje koje nije morsko područje utvrđeno u skladu sa članom 4, a koje se proteže do najdaljih stalnih lučkih objekata koji čine sastavni deo lučkog sistema, ili do granica određenih prirodnim geografskim obeležjima koja štite ušće ili slično zaklonjeno područje.

Termin „država luke” označava državu članicu prema čijoj jednoj ili više luka, ili iz čije luke brod ili plovilo pod zastavom koja nije zastava te države članice obavlja nacionalnu plovidbu. Prošireno je i značenje pojma „osobe smanjene pokretljivosti”, tako da sada pored osoba koje imaju određene teškoće pri upotrebi javnog prevoza, uključujući starije osobe, osobe sa invaliditetom, osobe sa oštećenjem ili osobe u invalidskim kolicima, uključuje i trudnice i osobe sa malom decom.

Za potrebe nove Direktive jedrenjak je brod koji se pokreće jedrima, čak i ako ima mehanički pogon koji se upotrebljava kao pomoćno pogonsko sredstvo ili pogon u slučaju nužde. Zbog nejednako rešenog pitanja korišćenja aluminijuma i njegovih legura, Direktiva definiše „ekvivalentne zamene” kao aluminijumsku leguru ili drugi negorivi materijal koji sam po sebi ili zbog dodane izolacije zadržava strukturu i integritet koji su ekvivalentni čeliku na kraju odgovarajućeg standardnog ispitivanja vatrootpornosti. Ispitivanje otpornosti na vatru je ispitivanje uzoraka odgovarajućih pregrada ili paluba zagrevanjem u ispitnoj peći do temperatura koje približno odgovaraju standardnoj krivoj vreme-temperature, u skladu sa metodom ispitivanja određenom u Međunarodnom kodeksu o postupcima ispitivanja vatrootpornosti iz 2010. godine. ${ }^{6}$

Terminom „tradicionalni brod” označavaju se sve vrste putničkih brodova projektovanih pre 1965. godine i njihove replike izgrađene uglavnom od originalnih materijala, uključujući one projektovane za podsticanje i promociju tradicionalnih veština i plovidbe, koji zajedno služe kao živi spomenici kulture i kojima se upravlja u skladu sa tradicionalnim načelima pomorskih veština i tehnike. Za razliku od toga, „jahta za razonodu ili plovilo za razonodu” označava plovilo koje se ne upotrebljava u komercijalne svrhe, bez obzira na vrstu pogona. Direktiva uvodi i određuje pojam značajnih popravki, izmena i preinačenja broda. Njima se smatra svaka promena kojom se bitno menjaju dimenzije broda (kao što je produženje dodavanjem novog središnjeg dela trupa), ili bitno menja kapacitet broda za prevoz putnika (npr. preinačenje palube vozila u prostore za smeštaj putnika), ili bitno produžuje radni vek broda (kao što je obnavljanje prostora za smeštaj putnika na jednoj celoj palubi), ili bilo koja vrsta broda menja u putnički brod. Preinačenja na brodovima isključivo radi postizanja veće sposobnosti prevladavanja oštećenja ne smatraju se značajnim izmenama.

\footnotetext{
${ }^{6}$ Međunarodni kodeks o ispitivanju vodootpornosti iz 2010. godine je deo Rezolucije IMO-a MSC.307(88) od 3. decembra 2010. godine.
} 
Direktiva se primenjuje na nove i postojeće putničke brodove dužine 24 metra i više, i brza putnička plovila, bez obzira na zastavu pod kojom plove, kada obavljaju nacionalnu plovidbu. ${ }^{7}$

Putnički brodovi dele se na klase prema morskom području u kom mogu ploviti. ${ }^{8}$ Direktivom je data kategorizacija morskih područja. ${ }^{9}$ Svaka država članica sastavlja i prema potrebi ažurira popis morskih područja pod svojom nadležnošću i određuje unutrašnju granicu morskog područja najbližeg njenoj obalnoj crti. Taj popis se objavljuje u javnoj bazi podataka dostupnoj na internetskim stranicama nadležnog tela za pomorstvo i o mestu objave tih podataka i unetim izmenama obaveštava Komisija.

Na svakom brodu mora biti stalno izložen opšti plan protivpožarne zaštite namenjen brodskim oficirima. ${ }^{10}$ Ti podaci mogu se navesti i u uputstvu čiji primerak mora imati svaki oficir, a jedan primerak mora biti stalno dostupan na brodu. Planovi i uputstva su na službenom jeziku države zastave. Ako taj jezik nije ni engleski ni francuski, mora postojati prevod na jedan od ta dva jezika. Za brod koji obavlja nacionalnu plovidbu u drugoj državi članici mora postojati prevod na službeni jezik te države luke kada taj jezik nije ni engleski ni francuski. Sve promene se redovno ažuriraju i unose u planove i uputstva u što kraćem roku od dana usvajanja.

\footnotetext{
${ }^{7}$ Direktiva se ne primenjuje na: ratne brodove i brodove za prevoz vojnih trupa, jedrenjake, brodove koji nemaju mehanički pogon, plovila izgrađena od materijala koji nije čelik ili jednakovredni materijal, a koja nisu obuhvaćena normama za brza plovila (Rezolucija MSC 36(63) ili MSC.97(73)), ili dinamički podržavana plovila (Rezolucija A.373 (X)), drvene brodove jednostavne gradnje, tradicionalne brodove, jahte za razonodu, brodove koji plove isključivo u područjima luka, brodove za usluge u vezi sa odobalnim projektima i tendere. Na brza putnička plovila koja su: ratna plovila i plovila za prevoz vojnih trupa, plovila za razonodu, plovila koja plove isključivo u područjima luka i plovila za usluge u vezi sa odobalnim projektima.

8 "Klasa A" putnički brod koji obavlja nacionalnu plovidbu u područjima A, B, C i D, „Klasa B” putnički brod koji obavlja nacionalnu plovidbu u područjima B, C i D, „Klasa C” putnički brod koji obavlja nacionalnu plovidbu u područjima C i D, i „Klasa D” putnički brod koji obavlja nacionalnu plovidbu u području D.

${ }^{9}$ A područje - morsko područje izvan područja B, C i D. B područje - znači morsko područje čije geografske koordinate ni na kojoj tački ne dosežu dalje od 20 milja od obalne crte, uzimajući u obzir srednju visinu morskih mena, ali koje je izvan morskih područja C i D. C područje morsko područje čije geografske koordinate ni na kojoj tački ne sežu dalje od 5 milja od obalne crte, uzimajući u obzir srednju visinu morskih mena, ali koje je izvan morskog područja D ako postoji. D područje - 3 milje od obalne crte, uzimajući u obzir srednju visinu morskih mena.

${ }^{10}$ Opšti plan protivpožarne zaštite za svaku palubu jasno pokazuje upravljačke stanice, različite požarne sekcije zatvorene pregradama klase , $A$ ', sekcije zatvorene pregradama klase , $B$ ' sa podacima o sistemu za otkrivanje požara i protivpožarni alarm, o sistemu za raspršivanje, uređajima za gašenje požara, sredstvima za pristup u razne odeljke, na palube, te o ventilacionom sistemu uključujući podatke o upravljanju ventilatorima, položajima zaklopki i identifikacijskim brojevima ventilatora za svaku sekciju.
} 
Direktivom se potvrđuje princip uzajamnosti država članica u pogledu priznavanja svedočanstva o sigurnosti putničkog broda, ili brzog putničkog plovila, i dozvola za rad koje je izdala druga država članica za putničke brodove koji obavljaju nacionalnu plovidbu. Naime, gradnja i održavanje trupa, glavnih i pomoćnih strojeva, te električnih i automatskih postrojenja moraju biti u skladu sa normama za klasifikaciju prema pravilima priznate organizacije ili ekvivalentnim pravilima koja primenjuje administracija u skladu sa članom 11, stav 2 Direktive 2009/15/EZ. Za nove i postojeće brodove značajne popravke, izmene i preinačenja, te pripadajuća oprema moraju biti u skladu sa zahtevima za nove brodove ili brodove izgrađene od ekvivalentnog materijala, dati su rokovi do kojih moraju biti usklađeni sa zahtevima iz Direktive. ${ }^{11}$ Svi novi i postojeći putnički brodovi koji ispunjavaju zahteve ove Direktive moraju imati Svedočanstvo o sigurnosti putničkog broda u skladu sa ovom Direktivom, čiji je obrazac utvrđen u Prilogu II, a izdaje ga administracija države zastave nakon obavljenog osnovnog pregleda. Pre izdavanja Dozvole za rad brzim putničkim plovilima koja obavljaju nacionalnu plovidbu u državi luke, administracija države zastave mora se usaglasiti sa državom luke o svim uslovima za obavljanja plovidbe brzih putničkih plovila u toj državi. Administracija država zastave u Dozvoli za rad navodi sve takve uslove. Pre uključivanja postojećih putničkih brodova klasa C i D u obavljanje redovne nacionalne plovidbe u državi luke, administracija države zastave mora pribaviti saglasnost države luke u pogledu tih pravila. Međutim, ako država članica smatra da su pravila koje zahteva administracija države luke neopravdana, ona o tome odmah obaveštava Komisiju, koja donosi akte koji sadrže njenu odluku o tome jesu li pravila opravdana.

Država članica obaveštava Komisiju o merama koje namerava doneti i dodaje pojedinosti neophodne za potvrdu održavanja odgovarajućeg nivoa sigurnosti. U roku od šest meseci od tog obaveštenja Komisija može da donese akte za provođenje koji sadržavaju njenu odluku da predložene mere nisu opravdane i od navedene države članice zahteva se da predložene mere izmene ili da ih ne donese. Donesene mere navode se u relevantnom nacionalnom zakonodavstvu i o njima se

${ }^{11}$ Brodovi izgrađeni od ekvivalentnog materijala pre 20. decembra 2017. godine moraju biti u skladu sa zahtevima iz ove Direktive do 22. decembra 2025. godine. Odstupajući od ove Direktive, država članica koja 20. decembra 2017. godine pod svojom zastavom ima više od 60 putničkih brodova izgrađenih od aluminijske legure može izuzeti od odredbi ove Direktive sledeće putničke brodove: klasa B, C i D izgrađene od aluminijske legure nakon 20. decembra 2017. godine, na razdoblje od 10 godina od tog datuma i putničke brodove klasa B, C i D izgrađene od aluminijske legure pre 20. decembra 2017. godine, u periodu od 12 godina od tog datuma pod uslovom da ti brodovi plove isključivo među lukama te države članice. Ro-ro putnički brodovi klase C kojima je kobilica položena, ili koji su bili u sličnoj fazi gradnje 1. oktobra 2004. ili nakon tog datuma, te svi ro-ro putnički brodovi klasa A i B moraju biti u skladu s članovima 6, 8 i 9 Direktive 2003/25/EZ. 
obaveštavaju Komisija i druge države članice. Svaka od ovih mera primenjuje se na sve putničke brodove iste klase ili na plovila koja plove pod istim navedenim uslovima, bez diskriminacije na osnovu njihove zastave, ili državne pripadnosti, ili mesta poslovnog sedišta prevoznika. Države članice mere prijavljuju Komisiji putem baze podataka koju Komisija uspostavlja i održava u tu svrhu te kojoj Komisija i države članice imaju pristup.

Komisija donosi akte za provođenje njene odluke o tome je li odluka države članice da obustavi plovidbu nekog broda, ili plovila, ili da uvede dodatne mere opravdana zbog ozbiljnog ugrožavanja sigurnosti života, ili imovine, ili okoline, a ako takva obustava ili nametanje dodatnih mera nisu opravdani, koji sadrže njenu odluku kojom se od dotične države članice zahteva da povuče tu obustavu ili mere. Sve akte neophodne za sprovođenje Direktive Komisija donosi u skladu sa postupkom ispitivanja iz člana 11, stav 2 Direktive.

Države članice koje nemaju morske luke i koje pod svojom zastavom nemaju putničke brodove ili plovila koji su obuhvaćeni područjem primene ove Direktive, mogu odstupiti od odredbi ove Direktive. ${ }^{12}$ Te države članice ne mogu dati dozvolu putničkim brodovima ili plovilima koji su obuhvaćeni područjem primene ove Direktive da plove pod njihovom zastavom dok ne prenesu i ne provedu ovu Direktivu.

U posebnim okolnostima u kojima je to opravdano odgovarajućom analizom Komisije i kako bi se izbegla ozbiljna i neprihvatljiva pretnja pomorskoj sigurnosti, zdravlju, životu na brodu ili uslovima rada ili morskoj okolini, ili neusklađenost sa pomorskim zakonodavstvom Unije, Komisija je ovlašćena za donošenje delegiranih akata kojima se ova Direktiva menja. Navedeni delegirani akti donose se najkasnije tri meseca pre isteka roka utvrđenog na međunarodnom nivou za prećutno prihvatanje, ili predviđenog datuma stupanja na snagu navedene izmene. U periodu koji prethodi stupanju na snagu takvog delegiranog akta države članice uzdržavaju se od svih inicijativa kojima je cilj uključivanje te izmene u nacionalno zakonodavstvo ili primena međunarodnog instrumenta.

Ovlašćenje za donošenje delegiranih akata dodeljuje se Komisiji na razdoblje od sedam godina počevši od 20. decembra 2017. godine. Svaki delegirani akt Komisija po donošenju, istovremeno, dostavlja Evropskom parlamentu i Veću. Ako nijedan od ova dva organa u roku od dva meseca od dostavljanja delegiranog akta na njega ne podnesu nikakav prigovor, ili ako su pre isteka tog roka obavestili Komisiju da neće podneti prigovore, akt stupa na snagu. 0 svom radu po delegiranim ovlašćenjima Komisija izrađuje izveštaj najkasnije devet meseci pre isteka perioda od sedam godina. Delegiranje ovlašćenja može i prećutno da se produži za još sedam godina, ukoliko se produženju ne usprotive Evropski

${ }^{12}$ Države članice o takvom odstupanju obaveštavaju Komisiju najkasnije do 21. decembra 2019. godine. 
parlament ili Veće najkasnije tri meseca pre kraja svakog sedmogodišnjeg perioda. Isto tako, Evropski parlament ili Veće u svakom trenutku mogu opozvati delegiranje ovlašćenja. Opoziv stupa na snagu narednog dana od dana objave te odluke u Službenom listu Evropske unije ili na kasniji dan naveden u njoj, ali ne utiče na valjanost delegiranih akata koji su već na snazi.

\section{3) ZNAČAJ ZA REPUBLIKU SRBIJU}

Direktiva predstavlja odgovor na zakonodavne aktivnosti IMO na povećanju bezbednosti putničkog saobraćaja kako bi se smanjili gubici u ljudskim životima i imovini na moru. Samom Direktivom predviđena je mogućnost države članice koja nema morske luke i koja pod svojom zastavom nemaju putničke brodove ili plovila koji su obuhvaćeni područjem primene Direktive da mogu odstupiti od njenih odredbi, o čemu u predviđenom roku obaveštavaju Evropsku komisiju. Mada zbog svog geografskog položaja, Republika Srbija nema morske luke, ona ima pomorsku mornaricu. Pitanje pomorske plovidbe u Republici Srbiji regulišu Zakon o pomorskoj plovidbi, Uredba o klasama putničkih brodova i Pravilnik o kategoriji plovidbe pomorskih brodova. ${ }^{13}$

Zakon daje definicije brodova za prevoz putnika i to: brzog putničkog broda, ro-ro putničkog broda i ro-ro trajekta. ${ }^{14}$ Prema važećem domaćem zakonodavstvu, putnike može da prevozi samo putnički brod, a broj putnika određuje se na osnovu tehničkih pravila, odnosno propisanih uslova, plovnih svojstava broda, raspoložive površine za smeštaj putnika, uređaja i opreme namenjene putnicima i higijenskih uslova. ${ }^{15}$ "Vlada propisuje klase putničkih brodova, bezbednosne zahteve za nove i postojeće putničke brodove i za brze putničke brodove, zahteve za stabilitet ro-ro putničkih brodova i njihovo isključivanje iz plovidbe, bezbednosne zahteve za lica sa smanjenom pokretljivošću, dodatne bezbednosne zahteve, ekvivalentne zamene

${ }^{13}$ Zakon o pomorskoj plovidbi, „Službeni glasnik RS”, br. 87/11, 104/13, 18/15, 113/17, 83/2018, Uredba o „Službeni glasnik RS”, broj 96/18, Pravilnik o kategoriji plovidbe pomorskih brodova, „Službeni glasnik RS”, broj 114/13.

${ }^{14}$ Zakon o pomorskoj plovidbi, član 4: „Brzi putnički brod je putnički brod registrovan za plovidbu morem kojem je najveća brzina u m/s jednaka ili veća od vrednosti dobijene formulom: $3,7 \nabla 0,1667$, gde je $\nabla$ istisnina na konstruktivnoj vodnoj liniji $\mathrm{u} \mathrm{m}^{3}$. Pod brzim putničkim brodom ne smatraju se neistisninski brodovi čiji je trup potpuno iznad površine usled delovanja aerodinamičkih sila generisanih površinskim efektom. Brodovi, zapremina istisnine $500 \mathrm{~m}^{3}$ i manje i najveće brzine manje od 20 čvorova, u plovidbi morem ne smatraju se brzim putničkim brodovima. Ro-ro putnički brod je putnički brod sa prostorom za ro-ro teret i prostorom posebne kategorije. Ro-ro trajekt je pomorski putnički brod opremljen tako da omogućava drumskim i železničkim prevoznim sredstvima da se ukrcavaju (roll on) na brod ili iskrcavaju (roll off) koji prevozi više od 12 putnika."

${ }^{15}$ Ibid., član 28. 
i izuzeća, vrste i rokove za vršenje pregleda putničkih brodova, sadržinu i obrazac svedočanstva o bezbednosti putničkog broda, bezbednosne uslove za nove i postojeće putničke brodove, kao i smernice i bezbednosne zahteve za putničke brodove, brze putničke brodove i za lica sa smanjenom pokretljivošću." ${ }^{16} \mathrm{Za}$ vršenje poslova kojima se obezbeđuje bezbedna plovidba, brod mora da ima odgovarajući broj članova posade sa propisanim zvanjima i ovlašćenjima o osposobljenosti i taj, najmanji, broj određuje Ministar, kao i njihova zvanja i ovlašćenja o osposobljenosti koje moraju da imaju, način određivanja dodatnog broja članova posade za pojedine brodove kada se utvrde nedostaci u odnosu na radne uslove na brodu, način izdavanja, kao i organ nadležan za izdavanje i obrazac uverenja o najmanjem broju članova posade. ${ }^{17}$ Domaći putnički brodovi, uključujući brze putničke brodove, moraju imati odobrenu procenu sigurnosti broda, međunarodno svedočanstvo o sigurnosti broad, ili privremeno međunarodno svedočanstvo o sigurnosti broda, oficira odgovornog za sigurnost broda, zapisnik o stalnom pregledu (CSR) i brodski sigurnosni sistem za uzbunjivanje. ${ }^{18}$ Stepen sigurnosti koji moraju da primenjuju domaći brodovi kada uplovljavaju u luke država članica SOLAS Konvencije utvrđuje Ministarstvo, u saradnji sa ministarstvom nadležnim za unutrašnje poslove. ${ }^{19}$

Uredba o klasama putničkih brodova sadrži definicije brzog putničkog plovila i broda sa punom palubom..$^{20}$ Kategorizacija morskih područja u članu 5 Uredbe izvršena je u skladu sa podelom morskih područja iz Direktive. Član 6 propisuje da se putnički brodovi prema području plovidbe razvrstavaju u klase, i te klase odgovaraju podeli klasa i morskih područja u Direktivi. Bezbednosni uslovi za nove i postojeće putničke brodove u domaćoj plovidbi dati su u Prilogu uz Uredbu i čine njen sastavni deo.

Novi i postojeći putnički brodovi klase A, B, C i D treba da ispunjavaju bezbednosne zahteve, u skladu sa članom 11 stav 2 Direktive 2009/15/EZ, poglavlja IV, V i VI SOLAS Konvencije sa izmenama i dopunama, kao i zahteve Međunarodne konvencije o teretnim linijama. ${ }^{21}$

Za brza putnička plovila važno je da su izgrađeni ili podvrgnuti značajnim popravkama, prepravkama ili izmenama 1. januara 1996. godine, ili posle tog datuma, ako ispunjavaju zahteve pravila $\mathrm{H} / 2 \mathrm{i}$ X/3 SOLAS Konvencije sa izmenama i dopunama. Izuzetak postoji za plovila čija je kobilica položena, ili su bili u sličnoj fazi gradnje najkasnije u junu 1998. godine, ili su im isporuka i narudžbina bile

\footnotetext{
${ }^{16}$ Ibid.

${ }^{17}$ Ibid., član 72.

${ }^{18}$ Ibid., član 164.

${ }^{19}$ Ibid., član 165.

${ }^{20}$ Uredba o klasama putničkih brodova, član 2.

${ }^{21}$ Ibid., član 8.
} 
najkasnije u decembru 1998. godine, ili u potpunosti ispunjavaju zahteve Pravilnika o bezbednosti dinamički podržavanih plovila. ${ }^{22}$ Brza putnička plovila izgrađena pre navedenog datuma, koja ispunjavaju zahteve Pravilnika o brzim plovilima, nastavljaju sa obavljanjem plovidbe za koju imaju odobrenje u skladu sa Pravilnikom. Brzim putničkim plovilima izgrađenim pre tog datuma, koja ne ispunjavaju zahteve Pravilnika, dozvoliće se obavljanje domaće plovidbe u državi članici Evropske unije samo ako su 4. juna 1998. godine već bila uključena u domaću plovidbu u toj državi. Gradnja i održavanje brzih putničkih plovila i njihove opreme je u skladu sa propisima za klasifikaciju brzih plovila priznate organizacije ili ekvivalentnim pravilima koje primenjuje uprava države zastave, u skladu sa članom 11 stav 2 Direktive 2009/15/EZ.

Iz Navedene analize proizlazi da su Zakon i podzakonski akti usklađeni sa odredbama svih ranije donetih Direktiva. Međutim, ostaje potreba harmonizacije svih ovih akata sa Direktivom EU/2017/2108.

\section{4) ZAKLJUČAK}

U Evropskoj uniji 22 članice imaju izlaz na more i gotovo 1.200 luka koje koristi 385 miliona putnika svake godine. ${ }^{23}$ Za sigurnost na brodu ključan je ljudski faktor i procedure koje treba da se primenjuju. Zato su uslovi života i rada na brodu i osposobljavanje članova posade u skladu sa međunarodnim zahtevima za uspešan završetak plovidbe. Različit geografski položaj i razuđenost obale utiču na primenu Direktive u svakoj državi članici. Korišćenje malih putničkih brodova ili brodova izgrađenih od ekvivalentnih materijala, uticalo je na ostavljanje mogućnosti državama članicama da tokom ograničenog perioda na takve putničke brodove primenjuju nacionalno pravo, pod uslovom da zadrže odgovarajući nivo sigurnosti. Tako se zbog posebnih geografskih i vremenskih karakteristika, ali i velikog broja ostrva sa kojima je potrebno održavati redovne i česte saobraćajne veze, Grčkoj dopušta odstupanje od zahteva za uspostavu morskih područja. Umesto toga, putnički brodovi se klasifikuju u skladu sa posebnim morskim plovnim putem na kojem plove, uz zadržavanje istih kriterijuma za klase putničkih brodova i iste sigurnosne norme. Kako bi se dodatno pojednostavile definicije morskih područja predviđene Direktivom 2009/45/EZ, sva ograničenja za određeni brod u pogledu plovidbe koja se odnose na njegovu udaljenost od mesta zakloništa navode se u

\footnotetext{
${ }^{22}$ Pravilnik o bezbednosti dinamički podržavanih plovila iz rezolucije IMO-a A.373 (10), sa svim naknadnim izmenama i dopunama, usvojen Rezolucijom Odbora za pomorsku bezbednost MSC 36 (63) Međunarodne pomorske organizacije od 20. maja 1994. godine, sa naknadnim izmenama i dopunama (u daljem tekstu: HSC Pravilnik)

23 "Ports: an engine for EU growth", https://eur-lex.europa.eu/legal-content/EN/TXT/?uri =legissum:320403_1 pristupljeno 18.1.2020.
} 
Svedočanstvu o sigurnosti putničkog broda. Država luke može obaviti inspekcijski pregled putničkog broda ili brzog putničkog plovila pod zastavom države koja nije država luke kada obavlja nacionalnu plovidbu, a što je poznato pod pravilom inspekcije države kojoj luka pripada.

Opšti ciljevi međunarodnog delovanja na poboljšanju sigurnosti putničkih brodova i uspostavljanju jednakih uslova treba ostvarivati u skladu sa Ugovorima, a države članice u tu svrhu deluju u okviru IMO s ciljem revizije i poboljšanja odredbi Konvencije SOLAS 1974, uzimajući u obzir smernice koje, uz primenu postojećih međunarodnih normi u toj oblasti, priprema Komisija.

Neobalnim državama članicama koje nemaju morskih luka i koje pod svojom zastavom nemaju brodove obuhvaćene područjem primene ove Direktive ne nameće se nesrazmerno administrativno opterećenje, pa takvim državama članicama treba dopustiti odstupanje od odredbi Direktive, odnosno te članice nisu obavezne preneti u domaće zakonodavstvo Direktivu sve dok su neispunjeni uslovi sadržani u njoj.

S obzirom na razlike u pristupu između zahteva Konvencije SOLAS 1974. i posebnih zahteva Unije u istoj oblasti potrebno je oceniti osiguravaju li zahtevi Konvencije SOLAS isti nivo sigurnosti. Zbog čestih promena pravila i tehničkih standarda na međunarodnom nivou, potrebna je brza reakcija organa EU kako bi redovno usklađivala svoje zakonodavstvo sa tim izmenama. Iz tog razloga, predloženo je da se Komisiji delegira ovlašćenje za donošenje akata u skladu s članom 290. UFEU u pogledu neprimenjivanja, za potrebe ove Direktive, izmena međunarodnih instrumenata, ako je potrebno i ažuriranja tehničkih zahteva.

Komisija uspostavlja i održava bazu podataka kako bi se povećala transparentnost i olakšalo obaveštavanje o izuzećima, materijalima i dodatnim sigurnosnim merama država članica, jer sve donete mere moraju biti javno dostupne. Ukoliko članice ne primenjuju pravila sadržana u Direktivi, Komisija je ovlašćena da reaguje propisivanjem mera. Važno je da se sve takve mere i sankcije pravilno provode i budu delotvorne, proporcionalne i odvraćajuće.

\section{5) LITERATURA}

Grabovac, Ivo, „Doprinos nekih međunarodnih konvencija sigurnosti plovidbe”, Pomorski zbornik, 40 (2002)1, 429-444;

Frančić, Vlado, Njegovan, Marko, Maglić, Lovoro, „Analiza sigurnosti putničkih brodova u nacionalnoj plovidbi", Pomorstvo, str. 539-555. 


\section{SAFETY RULES AND STANDARDS FOR PASSENGER SHIPS}

Summary: The use of maritime waterways for the transport of people and goods is steadily increasing. Despite the development of technology, the use of new materials and the improvement of ship dimensions, the loss of life at sea is still great. The reason for this is that the basic rules regarding the capacity of the ship or its technical capabilities are not respected. Therefore, global and regional organizations seek to adopt and harmonize different standards that would secure the safety of passengers and crew members. The rules range from improving living and working conditions on board, equalizing crew education and training certificates, adopting detailed technical rules for the construction, alteration and equipping of ships, as well as categorization of ships to limit their movement in the sea belts according to structural capabilities which they have. Some Member States of the European Union, due to their geographical specificity, have particular needs for the use of maritime routes. A number of legislative acts have been adopted by the bodies of the European Union, the most recent being Directive 2017/2108/EU. The aim is to align EU legislation with existing international standards, but also to harmonize the legislation of the Member States with one another, as well as to eliminate the unintended negative consequences that earlier acts have produced. Keywords: EU legislation, international standards, passenger ships. 